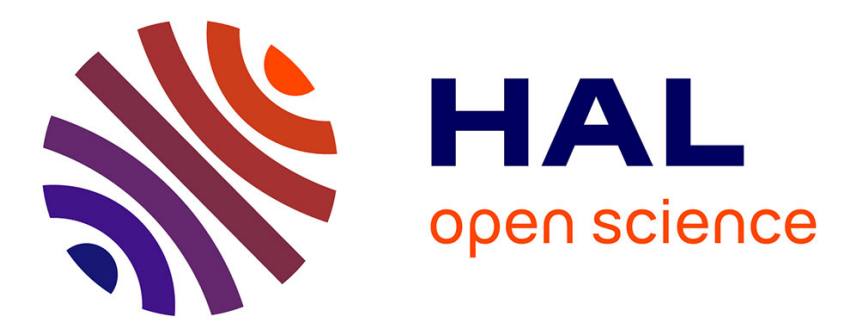

\title{
Tetracycline residues in honey after hive treatment
} Anne-Claire Martel, Sarah Zeggane, Patrick Drajnudel, Jean-Paul Faucon, Michel Aubert

\section{To cite this version:}

Anne-Claire Martel, Sarah Zeggane, Patrick Drajnudel, Jean-Paul Faucon, Michel Aubert. Tetracycline residues in honey after hive treatment. Food Additives and Contaminants, 2006, 23 (03), pp.265. 10.1080/02652030500469048 . hal-00577570

\section{HAL Id: hal-00577570 https://hal.science/hal-00577570}

Submitted on 17 Mar 2011

HAL is a multi-disciplinary open access archive for the deposit and dissemination of scientific research documents, whether they are published or not. The documents may come from teaching and research institutions in France or abroad, or from public or private research centers.
L'archive ouverte pluridisciplinaire HAL, est destinée au dépôt et à la diffusion de documents scientifiques de niveau recherche, publiés ou non, émanant des établissements d'enseignement et de recherche français ou étrangers, des laboratoires publics ou privés. 


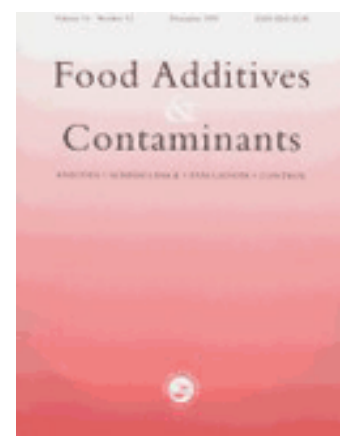

Tetracycline residues in honey after hive treatment

\begin{tabular}{|r|l|}
\hline Journal: & Food Additives and Contaminants \\
\hline Manuscript ID: & TFAC-2005-156.R2 \\
\hline Manuscript Type: & Original Research Paper \\
\hline Author: & 17-Oct-2005 \\
\hline Complete List of Authors: & $\begin{array}{l}\text { Martel, Anne-Claire; AFSSA Sophia Antipolis } \\
\text { Zeggane, Sarah; AFSSA Sophia Antipolis } \\
\text { Drajnudel, Patrick; AFSSA Sophia Antipolis } \\
\text { Faucon, Jean-Paul; AFSSA Sophia Antipolis } \\
\text { Aubert, Michel; AFSSA Sophia Antipolis }\end{array}$ \\
\hline Methods/Techniques: & HPLC, Screening - ELISA \\
\hline Additives/Contaminants: & Veterinary drug residues - tetracycline \\
\hline Food Types: & Honey \\
\hline
\end{tabular}

\section{SCHOLARONE ${ }^{\text {Tw }}$ Manuscripts}




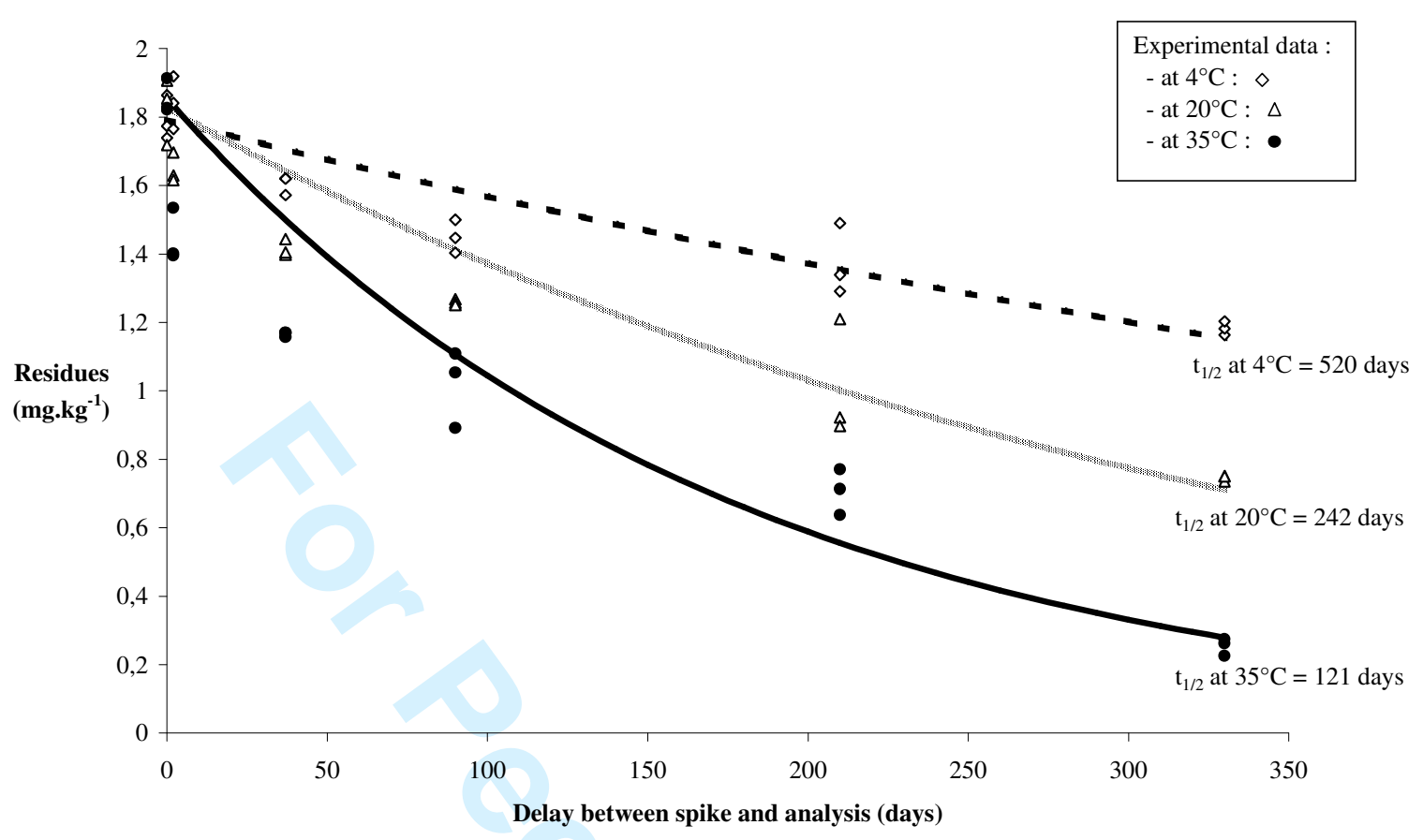




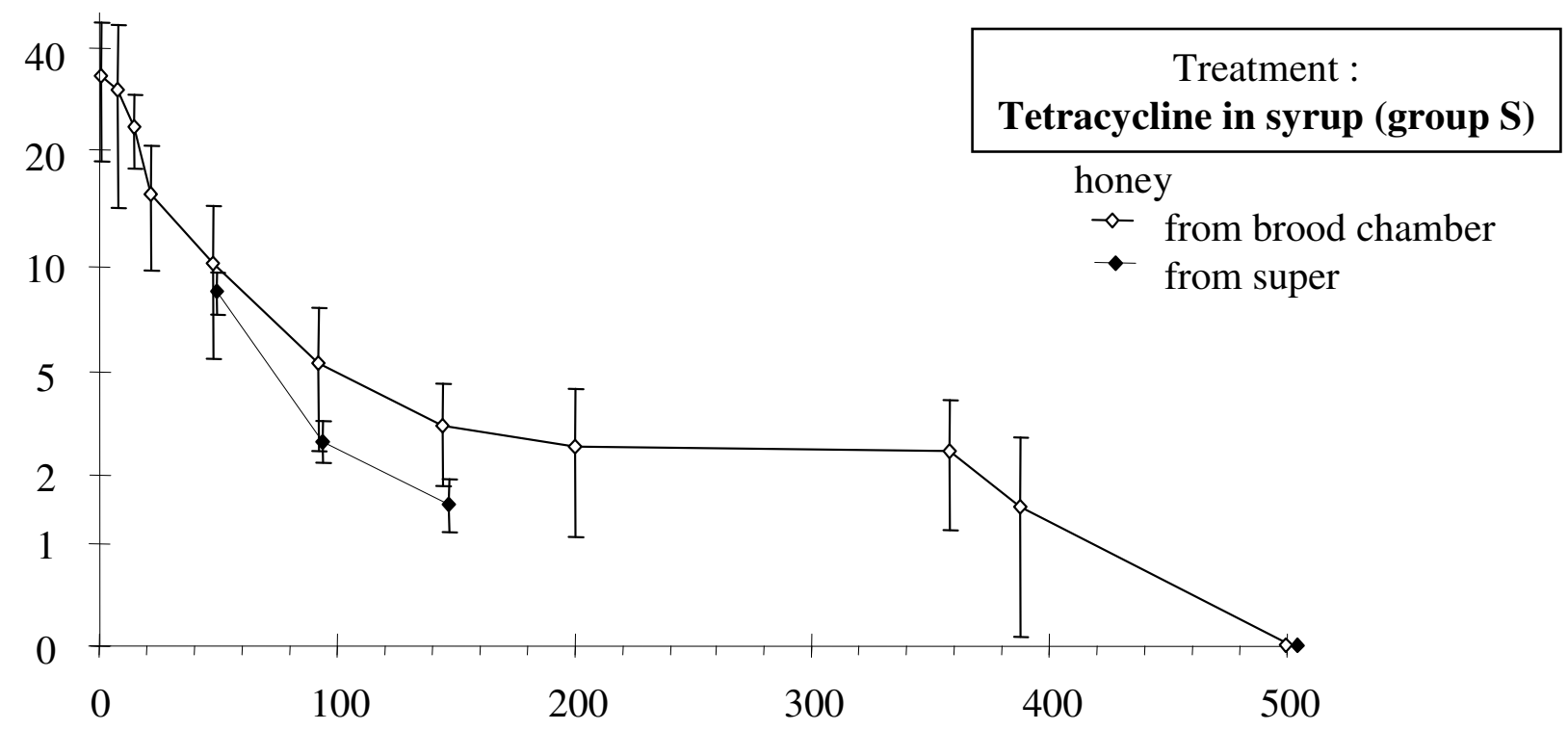

Mean $\mathrm{TC}$ residue levels in honey (mg.kg-1)
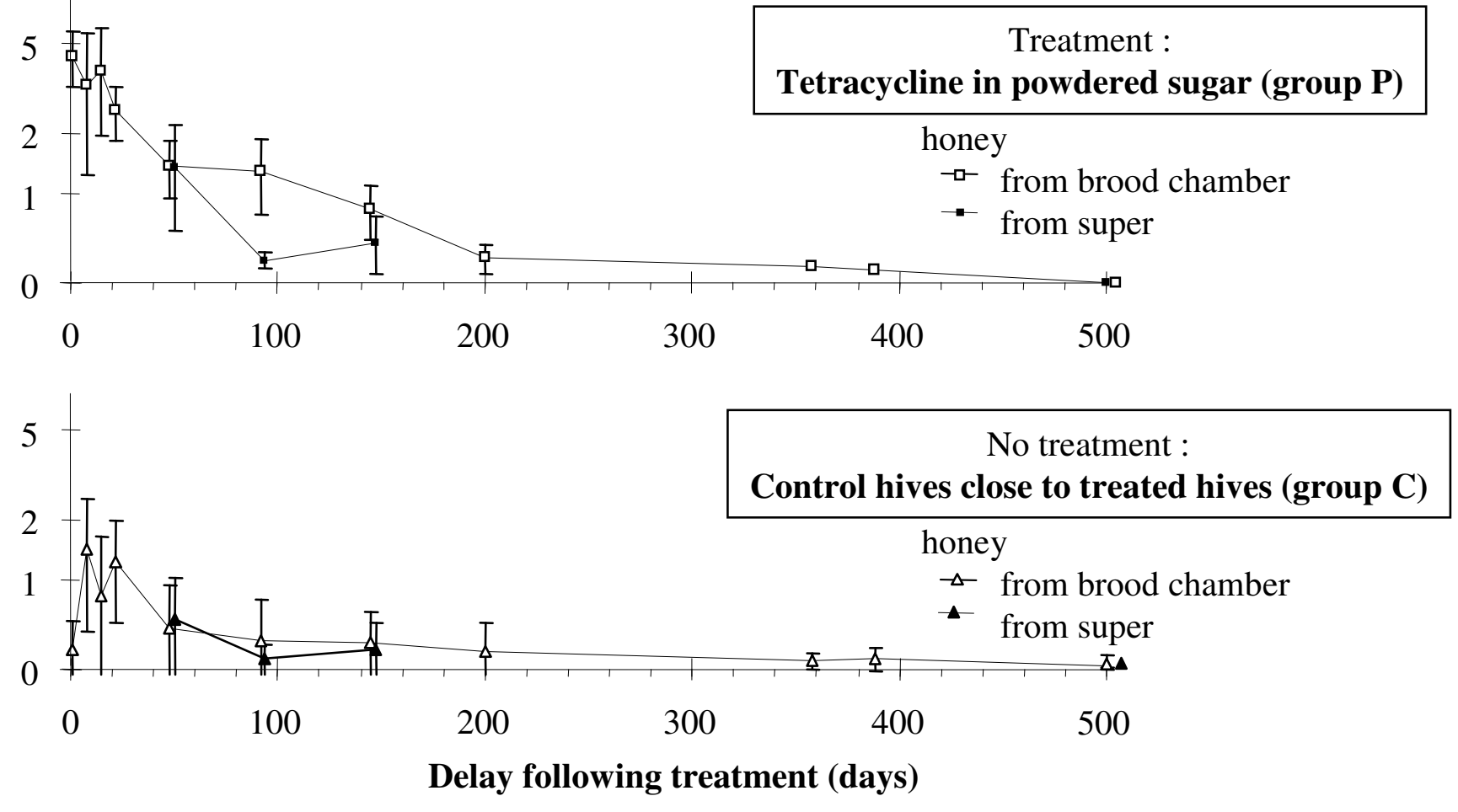

http://mc.manuscriptcentral.com/tfac Email: fac@tandf.co.uk 
Table 1. Tetracycline residues in hives

\begin{tabular}{|c|c|c|c|c|c|}
\hline $\begin{array}{l}\text { Date of } \\
\text { sampling }\end{array}$ & Sampling & in group DC & $\begin{array}{l}\text { Mean residu } \\
\text { in group C }\end{array}$ & $\begin{array}{l}\text { s }\left(\mathrm{mg} \cdot \mathrm{kg}^{-1}\right) \\
\text { in group P }\end{array}$ & in group $\mathrm{S}$ \\
\hline $\mathrm{T}-16$ & in brood chambers & ND & ND & ND & ND \\
\hline $\mathrm{D}+1$ & in brood chambers & ND & 0.16 & 4.34 & 40.7 \\
\hline $\mathrm{D}+8$ & in brood chambers & ND & 1.43 & 3.32 & 37.0 \\
\hline $\mathrm{D}+15$ & in brood chambers & ND & 0.72 & 3.82 & 28.8 \\
\hline $\mathrm{D}+22$ & in brood chambers & ND & 1.22 & 2.58 & 18.2 \\
\hline $\mathrm{D}+33$ & \multicolumn{5}{|c|}{ adding supers in all groups } \\
\hline \multirow{2}{*}{$\mathrm{D}+48$} & in brood chambers & ND & 0.37 & 1.36 & 11.2 \\
\hline & in supers & ND & 0.45 & 1.35 & 9.19 \\
\hline \multirow{2}{*}{$\mathrm{D}+92$} & in brood chambers & ND & 0.25 & 1.27 & 5.38 \\
\hline & in supers & ND & 0.08 & 0.18 & 2.82 \\
\hline \multirow{2}{*}{$\mathrm{D}+146$} & in brood chambers & ND & 0.23 & 0.72 & 3.22 \\
\hline & in honey harvested in supers & ND & 0.15 & 0.35 & 1.54 \\
\hline $\mathrm{D}+202$ & in brood chambers & $\mathrm{ND}$ & 0.14 & 0.20 & 2.72 \\
\hline$D+358$ & in brood chambers & ND & 0.06 & 0.13 & 2.57 \\
\hline \multirow{2}{*}{$\mathrm{D}+390$} & in brood chambers & ND & 0.08 & 0.10 & 1.50 \\
\hline & \multicolumn{5}{|c|}{ adding supers in all groups } \\
\hline \multirow{2}{*}{$\mathrm{D}+504$} & in brood chambers & ND & $0.03^{\text {(a) }}$ & ND & $0.01^{(\mathrm{c})}$ \\
\hline & in honey harvested in supers & ND & $\mathrm{ND}^{(\mathrm{b})}$ & ND & ND \\
\hline
\end{tabular}

Deleted: 40.67
Deleted: 37.01
Deleted: 28.81
Deleted: 18.17

$\mathrm{T}:$ day of the first application of TC

$\mathrm{D}:$ day of the last application of TC

ND : no residue detected

(a) : no residues were detected except in one super with a value of $0.17 \mathrm{mg} \cdot \mathrm{kg}^{-1}$

(b) : no residues were detected except in one super with a value of $0.026 \mathrm{mg} \cdot \mathrm{kg}^{-1}$

(c) : no residues were detected except in one super with a value of $0.043 \mathrm{mg} \cdot \mathrm{kg}^{-1}$ 
Table 2. Comparison between tetracycline concentration in brood chambers and in supers

\begin{tabular}{cccccc}
\hline $\begin{array}{c}\text { Days after } \\
\text { treatment }\end{array}$ & $\begin{array}{c}\text { Determination } \\
\text { coefficient }\left(\mathrm{r}^{2}\right)\end{array}$ & $\begin{array}{c}\text { Correlation } \\
\text { coefficient }(\mathrm{r})\end{array}$ & Significance of $\mathrm{r}$ & $\begin{array}{c}\text { Constant } \\
\text { term }\end{array}$ & $\begin{array}{c}\text { Significance of the } \\
\text { constant term }\end{array}$ \\
\hline 48 & 0.92 & 0.68 & $\mathrm{P}<0.0001-\mathrm{S}$ & 0.36 & $\mathrm{P}=0.32-\mathrm{NS}$ \\
\hline 92 & 0.86 & 0.43 & $\mathrm{P}<0.0001-\mathrm{S}$ & -0.13 & $\mathrm{P}=0.44-\mathrm{NS}$ \\
\hline 146 & 0.74 & 0.40 & $\mathrm{P}<0.0001-\mathrm{S}$ & 0.12 & $\mathrm{P}=0.30-\mathrm{NS}$ \\
\hline 504 & 0.93 & 0.14 & $\mathrm{P}<0.0001-\mathrm{S}$ & -0.001 & $\mathrm{P}=0.35-\mathrm{NS}$ \\
\hline
\end{tabular}

NS : not significant

$\mathrm{S}$ : significant 
2

4

5

6

7

8

9

10

11

12

\section{Tetracycline residues in honey after hive treatment}

Martel ${ }^{1}$ Anne-Claire, Zeggane Sarah, Drajnudel Patrick, Faucon Jean-Paul and Aubert Michel

Agence Française de Sécurité Sanitaire des Aliments (AFSSA) Site de Sophia Antipolis,

Laboratoire d'Études et de Recherches sur les Petits Ruminants et les Abeilles (LERPRA),

Unité de Pathologie de l'Abeille,

105 route des Chappes, F-06902 Sophia Antipolis Cedex, France

\footnotetext{
${ }^{1}$ Corresponding author. Phone : (33) 492943739 ; Fax : (33) 492943701
}

E-mail address : ac.martel@afssa.fr 


\begin{abstract}
Tetracyclines are used to control bacterial diseases like European and American foulbrood which may cause severe losses in honey bee population and honey production. This study, using 24 hives randomly distributed into four groups of 6 hives, was performed to measure the occurrence of tetracycline (TC) residues in honey following two types of TC application. Two groups of colonies were treated 3 times with $0.5 \mathrm{~g}$ of $\mathrm{TC}$ in 1 litre of syrup (group $\mathrm{S}$ ) or in $10 \mathrm{~g}$ of powdered sugar (group P). Six hives of a first control group (group C) fed with untreated syrup were installed at 20 and 45 metres from groups $\mathrm{S}$ and $\mathrm{P}$ respectively. A second control group (group DC) was set up 3 $\mathrm{km}$ away. Honey was sampled at different times from all hives and honey artificially contaminated with TC was stored in the laboratory at 4,20 and $35^{\circ} \mathrm{C}$, and all samples were analysed by ELISA and HPLC methods. One day after the last application, the mean TC concentration in brood chamber honey was ten times higher in group $\mathrm{S}\left(40.7 \mathrm{mg} \cdot \mathrm{kg}^{-1}\right)$ than in group P $\left(4.34 \mathrm{mg} \cdot \mathrm{kg}^{-1}\right)$. After 8 days, TC residues were detected in all hives of group C. After 146 days, the mean TC concentration in harvested honey was $1.54,0.35$, and $0.15 \mathrm{mg} \cdot \mathrm{kg}^{-1}$ for groups $\mathrm{S}, \mathrm{P}$ and $\mathrm{C}$ respectively. The control group $\mathrm{C}$ had been contaminated with $\mathrm{TC}$ by drifting. In all hives of the group DC, no residues were detected at any time during the study. The honey collected at day 504 did not contained any detectable TC residues, except in one super from group $\mathrm{C}\left(0.026 \mathrm{mg}^{\mathrm{kg}} \mathrm{kg}^{-1}\right)$. The half-life of TC in honey from supers was similar in groups $\mathrm{C}, \mathrm{S}$ and $\mathrm{P}$ and equal to 65 days. This duration was twice lower than in honey stored in laboratory in similar conditions : at $35^{\circ} \mathrm{C}$ in the dark $\left(\mathrm{t}_{1 / 2}=121\right.$ days $)$. In honey stored at $20^{\circ} \mathrm{C}$, TC was quite stable and its half-life was 242 days. The data from these experiments indicate levels of TC residues in honey after a treatment in hives, their persistence and diffusion into the apiary. These results show that the TC must be used with precaution in honey production.
\end{abstract}

Keywords : Honey, antibiotics, tetracycline, residues, stability 


\section{Introduction}

Bacterial diseases of the honey bee Apis mellifera may severely decrease the honey bee population and honey production, causing significant damage to the beekeeping industry. Two of most important bacterial diseases that affect the larvae of the honey bee Apis mellifera are American foulbrood and European foulbrood caused by Paenibacillus larvae and Melissococcus pluton, respectively. These pathogens have been treated in bee colonies using antibiotics for many years. Due to their low cost and large availability, tetracyclines are most commonly used in several countries even as a preventive treatment (Evans 2003).

This treatment risks tetracycline residues in honey as reported by many authors. Among them, Faucon et al. (2001) found tetracyclines residues in 34 out of 75 French lavender honeys, and 14 of them had residues above $0.020 \mathrm{mg} \cdot \mathrm{kg}^{-1}$. In 2002, residues of tetracyclines (ranging from 0.019 to $2.152 \mathrm{mg} \cdot \mathrm{kg}^{-1}$ ) were detected in 19 of the 113 French honey samples collected according to the 96/23/EC Directive (National surveillance plan, note DGAL 2002). Only two producers had previously indicated they used tetracyclines (Martel et al. 2003).

Usleber et al. (1996) showed that seven days after the last treatment of bee colonies with tetracycline (TC) or oxytetracycline (OTC) in sucrose $\left(10 \mathrm{mg} \cdot \mathrm{g}^{-1}\right)$, honey contained more than 0.4 $\mathrm{mg}$ of TC/kg and 1.5 to $3.5 \mathrm{mg}$ of OTC/kg. Matsuka et al. (1990) showed that only two days after OTC administration, this antibiotic was already distributed in the whole hive (OTC concentration ranged between 15 and $91 \mathrm{mg} \cdot \mathrm{kg}^{-1}$ depending on the proximity to the feeder) and was equalized within one week. Both authors observed that the degradation of OTC in hive was not complete after 6 weeks. 
However, currently, no maximum residue limits (MRL) have been defined for tetracyclines and their metabolites in honey contrary to other matrices such as milk, meat, liver and kidney whose MRL range between 0.1 and $0.6 \mathrm{mg} \cdot \mathrm{kg}^{-1}$. Switzerland and Belgium have established a tolerance limit of $0.02 \mathrm{mg}$ of tetracyclines and their metabolites/kg of honey. Above this limit, honey must be removed from the market. Consequently, the present study was designed to contribute to a better knowledge of the consequences of antibiotic treatments on their residue levels in honey. Two of the current protocols used by beekeepers were tested : antibiotics in syrup or in powdered sugar given to colonies 4 weeks before the honey flow. The decline of TC in hive has been followed in brood chamber and super honey for 504 days following antibiotic treatment and compared to that in honey samples stored at different temperatures.

\section{Experimental}

\section{Materials and reagents}

The homogenisation equipment for TC extraction from honey samples consisted of a Vortex-mixer with variable speed from Fisher Bioblock Scientific (Illkirch, France) and an agitation system for centrifuge tubes from New Brunswick Scientific Co. (N.J., USA). The centrifuge GR 4.11 model from Jouan (Saint-Herblain, France) was used to eliminate pollen and other impurities in honey samples.

The TC analysis was performed by HPLC on an Agilent 1100 from Agilent (Karlsruhe, Germany) consisting of a quaternary pump, an autosampler with a $20 \mu$ loop and a photodiode array detector (DAD). A second analytical method was based on the ELISA using a Ridascreen® Tetracyclines kit from R-Biopharm (Darmstadt, Germany) that contains all the reagents required for the assay. Test kits were stored at $4^{\circ} \mathrm{C}$. The detection system for ELISA was a Multiskan Plus MK2 spectrophotometer from Elvetec Service (Marseille, France). 
Tetracycline hydrochloride (TC) was purchased from Sigma Aldrich (Saint-Quentin-Fallavier, France). TC standards solutions were prepared in methanol $\left(100 \mathrm{mg} \cdot \mathrm{l}^{-1}\right)$ and kept at $-18^{\circ} \mathrm{C}$ for one month in dark glass bottles. Just before use, these solutions were diluted to the required concentrations with $0.05 \mathrm{M}$ ortho-phosphoric acid or PBS for HPLC or ELISA respectively.

\section{Tetracycline analysis}

Two analytical methods were employed to detect TC in honey samples : HPLC and ELISA. At the beginning of the experiment, TC analyses were undertaken by HPLC because residues levels were high. Under the level of $500 \mu \mathrm{g} \cdot \mathrm{kg}^{-1}$, the quantitative analysis was made by ELISA. According to the manufacturer description, the ELISA test kit recognizes several compounds of the chemical class of tetracyclines, including TC to which this test is reported to display a cross-reactivity of $100 \%$

\section{HPLC}

The procedure for extraction and analysis of TC was based on the Jürgens' (1981) method but was modified as follows. Honey ( $1 \mathrm{~g}$ ) was mixed in a beaker with $3 \mathrm{ml}$ of $0.05 \mathrm{M}$ ortho-phosphoric acid and transferred to a $10 \mathrm{ml}$ flask. The beaker was then rinsed with $5 \mathrm{ml}$ of $0.05 \mathrm{M}$ ortho-phosphoric 
acid and the volume of the flask was completed to $10 \mathrm{ml}$. The extract obtained was ready for HPLC analysis after filtration on $0.45 \mu \mathrm{m}$ filter.

The liquid chromatographic column was a Hypersil BDS C18, $5 \mu \mathrm{m}, 250$ x $4.0 \mathrm{~mm}$ I.D. from Merck Eurolab-Prolabo. The mobile phase was 0.05 M ortho-phosphoric acid/acetonitrile (80:20, $\mathrm{v} / \mathrm{v}$ ) at a flow-rate of $1 \mathrm{ml} \cdot \mathrm{min}^{-1}$. Detection of TC was made at the $360 \mathrm{~nm}$ wavelength. The injection volume was $20 \mu \mathrm{l}$ and an external calibration was employed. The chromatographic runs were performed at $15^{\circ} \mathrm{C}$. Limits of detection and quantification were 200 and $500 \mu \mathrm{gg}^{-1}$ respectively. Limits of detection (LOD) and quantification (LOQ) were calculated by a signal to noise ratio of $3: 1$ and of 10:1 (Directive 91/414/EEC modified by Directive 96/46/CE and Explantory Note EEC/844/87, European Union, Brussels).

\section{ELISA}

Honey (1 g) was agitated using Vortex-mixer with $50 \mathrm{ml}$ of PBS. This extract was subsequently centrifuged at $3290 \mathrm{~g}$ during $30 \mathrm{~min}$ at room temperature to eliminate pollen and other impurities. According to the procedure described for the kit, $50 \mu \mathrm{l}$ of TC standards prepared in PBS and the extracts of honey were added to the bottom of each well in duplicate. At the last step, in presence of $\mathrm{TC}$, the addition of the stop reagent (which contains $1 \mathrm{M}$ sulphuric acid) leads to a colour change from blue to yellow. The measurement is made by photometry at $450 \mathrm{~nm}$. The absorption is inversely proportional to the TC concentration in the sample. Limits of detection and quantification were 10 and $15 \mu \mathrm{g} \cdot \mathrm{kg}^{-1}$ respectively.

\section{Protocols}

\section{Stability of tetracycline in honey stored under laboratory conditions}

The honey used in this study had been harvested in the laboratory apiary at Sophia Antipolis at the end of summer 2002 from hives that had never been treated with TC. These hives were kept in a 
mixed environment of typical Mediterranean forest (Quercus suber and Q. ilex) and meadows. Therefore, additionally to Mediterranean oaks, sources of pollen, nectar and honey-dew were from a large variety of wild plants such as Dorycnium pentaphyllum, sages (Salvia sp.), thyme (Thymus sp.), rosemary (Rosmarinus officinalis), heather (Erica arborea and E. sp.), arbutus (Arbutus unedo), Inula viscosa, Solidago sp. This honey reflected this polyfloral origin.

Three aliquots of $200 \mathrm{~g}$ of honey were spiked each with $4 \mathrm{ml}$ of $100 \mathrm{mg} . \mathrm{l}^{-1}$ of TC solution prepared in methanol and manually homogenised using a spatula during 10 minutes. These samples with an initial level of TC equal to $2 \mathrm{mg} . \mathrm{kg}^{-1}$ were then kept in darkness at three different temperatures (4, 20 and $35^{\circ} \mathrm{C}$ ). A fourth honey sample was added with $4 \mathrm{ml}$ of methanol and used as control sample during analyses. TC analyses were performed on 3 aliquots of each of these samples at day 0, 2, 37, 90, 210 and 330 following this preparation.

\section{Tetracycline found in honey following treatments of colonies}

Honey bee colonies

Experiments were conducted on 24 10-frame Langstroth new hives purchased at Ickowicz (Bollène, France) equipped with crown board feeders. Colonies belonged to the small black local race of Apis mellifera mellifera of our laboratory's experimental apiary. They were transferred to new foundation combs on April 2002. Hives were randomly distributed into four groups of 6 hives. Two treated groups called 'the syrup' (S) and 'the powdered sugar' (P) and one untreated group called 'the control' (C) were installed at the same site in the premises of the laboratory at Sophia Antipolis, Alpes-Maritimes, France. For limiting drifting as much as possible, the distance between hives of the treated groups and the distance between treated and control hives (group C) were 10 metres and 20 metres respectively. The fourth group of 6 hives was disposed $3 \mathrm{~km}$ apart from the others and will be called 'the distant control' (DC) in the following lines. 
Varroa destructor was preventively controlled using Apivar ${ }^{\circledR}$ : two stripes were inserted in the hives during ten weeks starting in September 2002, in August 2003 and in September 2004. Additionally, a five-week treatment was initiated in May 2004 following the observation of parasites. All hives were artificially fed with commercial syrup (2.5 litres/hive of Apiinvert supplied from Nevières - Valensole, France) in September 2003 and April 2004 and with candy (2.5 kg/hive of Apifonda from the same supplier) in November 2003 and January 2004.

Colony mortality was observed at day 146 (1 colony of group S), day 202 (2 colonies of group P), day 358 (1 colony of group P and 1 of group C) and day 504 (1 colony of group S). Similar mortality rates, colony weakness and a development of wax moth especially in supers were also observed by other beekeepers in the area and were attributed to the very high temperatures during summer 2003.

\section{Treatment}

Before the start of the experiment, analyses of TC were realised on honey collected in every combs of all hives 16 days before the first TC application. TC was applied to hives at the end of winter according to two modes of application : syrup or powdered sugar. Groups $\mathrm{S}$ and $\mathrm{P}$ received 3 applications of TC (0.5 g each per colony) 7 days apart (on the 26 February, 6 and 12 March 2003). Group C received saccharose syrup only at the same dates.

Syrup (saccharose/water 50:50 (w/v)) was prepared by mixing $5 \mathrm{~kg}$ of saccharose and 5 litres of water using a magnetic agitator during one night. TC syrup was processed extemporarily by mixing during 4 hours $3.785 \mathrm{~g}$ of TC in 7.5 litres of saccharose syrup. Each day of treatment, each colony of groups $\mathrm{C}$ and $\mathrm{S}$ received 1 litre of syrup or TC syrup respectively, precisely measured with a graduated cylinder. 
TC powdered sugar was processed by mixing manually $3.5 \mathrm{~g}$ of $\mathrm{TC}$ and $70 \mathrm{~g}$ of powdered sugar. Each day of treatment, each colony of group P received $10 \mathrm{~g}$ of TC powdered sugar equally dropped between combs. An aliquot of each mix (saccharose syrup, TC saccharose syrup and TC powdered sugar) was kept at $4^{\circ} \mathrm{C}$ immediately after preparation for TC titration.

Honey sampling in colonies

In every colony, all frames of each brood chamber and super were identified with a number. On day $1,8,15,22,33,48,92,146,202,358,390$ and 504 post treatment, individual samples of $10 \mathrm{~g}$ of honey were taken repetitively from the same five frames in the brood chamber and in the super from uncapped or sealed honey cells. Honey samples were filtered through a nylon sieve into a clean polyethylene jar appropriately labelled (identification of the colony, brood chamber or super, frame, treatment mode, date of sampling). All samples were stored at $4^{\circ} \mathrm{C}$ before analysis.

Until 22 days after treatments, each sample was analysed individually. After this date, the five samples from the same colony were pooled before analysis.

Supers were added 33 days (14 April 2003) after the last treatment. On the 5 August 2003 (i.e. 113 days later), honey of each super was harvested separately for group DC, group C, group P and group S successively. The extractor was cleaned between each extraction. Honey harvests were weighed using an electronic balance (accuracy $=+/-0.05 \mathrm{~kg}$ ) and were ranged from 15.5 to $18 \mathrm{~kg}$ $($ mean $=16.5 \mathrm{~kg})$, from 1 to $20 \mathrm{~kg}($ mean $=12.7 \mathrm{~kg})$, from 7.1 to $17 \mathrm{~kg}($ mean $=12.6 \mathrm{~kg})$ and from 11.6 to $16.8 \mathrm{~kg}$ (mean $=14.4 \mathrm{~kg}$ ) for groups DC, C, P and S respectively. 


\title{
Data analysis
}

Degradation of tetracyline in spiked honey stored in laboratory conditions at various temperatures

We assessed that the degradation speed followed a first-order kinetic model according to the equation :

$$
\mathrm{k}=-\ln \left(\mathrm{C} / \mathrm{C}_{0}\right) / \mathrm{t}
$$

where $\mathrm{k}$, the degradation rate is expressed in day ${ }^{-1}, \mathrm{C}$ and $\mathrm{C}_{0}$, the mean TC concentrations (mg.kg ${ }^{-1}$ ) of the three samples taken at day $\mathrm{t}$ and day 0 respectively. $\mathrm{k}$ was estimated by linear regression analysis. The persistence of the TC was estimated by the half-life time $\left(\mathrm{t}_{1 / 2}\right)$ using equation 2 :

$$
\mathrm{t}_{1 / 2}=\ln 2 / \mathrm{k}
$$

\begin{abstract}
Comparison between the mean tetracycline titre of the five honey samples of the same hives and the tetracycline titre measured on the pooled samples

At day 1, 8, 15 and 22, TC titre was measured independently on each honey sample (one sample per frame) and on the pool of the five samples taken from the same brood chamber. Means of the titres of these five samples and titres of the corresponding pools were compared using the mean square correlation method.
\end{abstract}

\footnotetext{
Statistical analyses were realised with the appropriate module of JMP® software (JMP® Design of Experiments, Version 5, 2002, SAS Institute Inc., Cary, NC, USA 27513) and multiple comparisons of means were performed on all pairs of means using Tukey-Kramer honestly significant difference test included in the same software.
} 


\section{Results and discussion \\ Stability of tetracycline in honey stored under laboratory conditions}

All linear adjustments according to the degradation speed model (1) were highly significant which ever was the storage temperature (Prob (theoretical $\mathrm{F}$ for 1 and 16 degrees of freedom $>\mathrm{F}_{\mathrm{obs}}$ ) $<$ 0.0001). $\mathrm{k}$ was evaluated to $1.33410^{-3}, 2.86210^{-3}$ and $5.73710^{-3}$ day $^{-1}$ at 4,20 and $35^{\circ} \mathrm{C}$ respectively. Logically, higher storage temperatures resulted in a more rapid degradation of TC : half-life time was evaluated to 520,242 and 121 days at 4,20 and $35^{\circ} \mathrm{C}$ respectively (figure 1 ). In other words, at $35^{\circ} \mathrm{C}$, which is the internal hive temperature, the degradation of TC is twice faster than at ambient temperature $\left(20^{\circ} \mathrm{C}\right)$. In our study, the honey had a $\mathrm{pH}$ equal to 4.5. As in general, the $\mathrm{pH}$ of honey ranges between 3.2 and 4.5 , the observed stability of $\mathrm{TC}$ is consistent with the known stability of tetracyclines in acidic medium (Chambonnaud 1968, Puyt 1997).

[Insert figure 1 about here]

\section{Tetracycline found in honey following treatments of colonies}

No residues of TC were detected in any samples 16 days before treatments (T-16). Treatments with TC were realised at $\mathrm{T}, \mathrm{T}+8$ days and $\mathrm{T}+14$ days. Analyses of $\mathrm{TC}$ in each aliquot of preparation were realised by HPLC. Values measured for TC in syrup preparations used were $0.51,0.44$ and $0.35 \mathrm{~g}$ of TC/l of syrup at day 0,8 and 14 respectively. The TC values measured in the powdered sugar preparations were $0.38,0.5$ and $0.49 \mathrm{~g}$ of $\mathrm{TC} / \mathrm{g}$ of powdered sugar respectively. Most of these values are very close to the expected titre of $0.5 \mathrm{~g}$ of TC/1 of syrup and $0.5 \mathrm{~g}$ of TC/g of powdered sugar.

Comparison between the mean tetracycline titre of the five honey samples of the same hives and the tetracycline titre measured on the pool of these samples

For groups $\mathrm{C}, \mathrm{S}$ and $\mathrm{P}$, the correlation between the mean of the individual measures performed on the honey taken from 5 frames and the measure on the pool of these samples is very highly 
significant with $\mathrm{r}=1.00,0.99$ and 0.94 respectively $(\mathrm{P}<0.0001)$. The slopes of the three correlation lines are not significantly different from 1 and the intercepts (equal to $0.06,0.16$ and 0.13 respectively) are not significantly different from 0 . These slope and intercept values reveal that the measure on the pooled samples is a very precise and a non biased estimation of the mean of the measures of the individual samples. Consequently, after day 22, all titrations have been processed on pooled samples only.

\section{Tetracycline residues in hives}

TC residue levels in the honey samples collected from brood chamber and super are described in figure 2 and table 1.

[Insert figure 2 about here]

[Insert table 1 about here]

Honey samples from brood chambers

One day after the last application, TC residues were detected in honey from brood chamber of all hives of groups $\mathrm{S}$ and P. Values ranged from 22.7 to $71.0 \mathrm{mg} \cdot \mathrm{kg}^{-1}$ (mean $=40.7 \mathrm{mg} \cdot \mathrm{kg}^{-1}$ ) and from 2.48 to $5.32 \mathrm{mg} \cdot \mathrm{kg}^{-1}$ (mean $=4.34 \mathrm{mg} \cdot \mathrm{kg}^{-1}$ ) for groups $\mathrm{S}$ and $\mathrm{P}$ respectively. Out of the 6 hives of the control group C, 3 had TC residues with values ranging from 0.06 to $0.72 \mathrm{mg} \cdot \mathrm{kg}^{-1}$ (mean $=0.16$ mg. $\mathrm{kg}^{-1}$ for the whole group $\mathrm{C}$ ). The mean residues titre of group $\mathrm{S}$ is significantly higher than the means of groups $\mathrm{P}$ and $\mathrm{C}$ with no significant difference between these latest groups (Tukey-Kramer test with $\alpha$ equal to $5 \%$ ). No TC residues were detected in the group DC.

Several conclusions may be drawn from the TC measurements in honey at day one : (i) the incorporation of TC in honey is very rapid; (ii) the treatment with syrup entailed a ten times higher concentration of TC in honey than treatment with powdered sugar. Both results are coherent with our observation of the rapid removal of syrup by bees and its storage in cells. As some traces of 
powdered sugar remained on the top of frames, TC was not so much incorporated in honey than when TC was given in syrup; (iii) non-treated hives may be contaminated with TC through drifting from neighbouring TC treated hives. This contamination is related with distance between hives : whereas no TC residues were detected in the group DC, two of the three contaminated hives of group $\mathrm{C}$ were at the edge of this group i.e. at 20 metres from the first hive of group $\mathrm{S}$. The farthest hive of this group was at 35 metres from the first hive of group S.

The rapid dissemination of syrup into the whole colony is a well known phenomenon : Courtois et al. (1958) demonstrated that 24 hours after application of syrup marked with ${ }^{198} \mathrm{Au}$, all bees of the hive were radioactive with all the radioactivity detected in the digestive tract. In a similar experiment, Nixon and Ribbands (1952) observed that following application of radioactive syrup to a colony, 43 to $60 \%$ of all bees of the colony were radioactive within 27 hours. Whereas, foragers became radioactive faster and at a higher rate (76\%) than the rest of the colony, this enhanced their role of TC carrier to other colonies by drifting. All the large larvae in unsealed cells became radioactive within 48 hours. McKee et al. (2003) confirmed that OTC treatment reaches larvae rapidly : on the day following a treatment with 0.3 to $1 \mathrm{~g}$ of OTC, they measured in larvae an OTC level ranging between 13.3 and $172.2 \mathrm{mg} \cdot \mathrm{kg}^{-1}$.

\begin{abstract}
After 8 days, TC residues were detected in all hives of group C. The TC level decreased significantly in all groups whereas the differences previously observed between groups were maintained. The mean TC level of group S remained significantly higher than those of group P and C until day 358 post treatment. After approximately one year (358 days), mean TC residue levels were $2.57,0.13$ and $0.06 \mathrm{mg} \cdot \mathrm{kg}^{-1}$ for groups $\mathrm{S}, \mathrm{P}$ and $\mathrm{C}$ respectively. At day 390 , mean values of TC residues were $1.50,0.10$ and $0.08 \mathrm{mg} . \mathrm{kg}^{-1}$ in groups $\mathrm{S}, \mathrm{P}$ and $\mathrm{C}$ respectively.
\end{abstract}


No residues were detected after 504 days in 3 hives on 4 for group S, in 2 hives on 3 for group P and in 4 hives on 5 for group C. At this date (D+504), residue levels detected became weak. It is worthwhile to note that at this time, the highest value $\left(0.17 \mathrm{mg} \cdot \mathrm{kg}^{-1}\right)$ is measured in group $\mathrm{C}$.

Honey samples from supers

At day 48 (15 days after adding supers), TC residues were detected in harvested honey in all hives of groups $\mathrm{S}$ and $\mathrm{P}$ (except for 2 hives of group $\mathrm{S}$ which did not produce any honey). Values ranged between 7.94 and $10.68 \mathrm{mg} \cdot \mathrm{kg}^{-1}\left(\right.$ mean $\left.=9.19 \mathrm{mg} \cdot \mathrm{kg}^{-1}\right)$ and between 0.61 and $2.58 \mathrm{mg} \cdot \mathrm{kg}^{-1}(\mathrm{mean}=$ $1.35 \mathrm{mg} \cdot \mathrm{kg}^{-1}$ ) for groups $\mathrm{S}$ and $\mathrm{P}$ respectively. TC residues measured in the 3 hives of group $\mathrm{C}$ which produced honey ranged between 0.41 and $1.31 \mathrm{mg} \cdot \mathrm{kg}^{-1}$ (mean of the 5 hives of group $\mathrm{C}=$ $\left.0.45 \mathrm{mg} \cdot \mathrm{kg}^{-1}\right)$.

At day 92 and 146, the mean TC level of group S was significantly higher than the means of groups $\mathrm{P}$ and $\mathrm{C}$ which were not significantly different (Tukey-Kramer test with $\alpha$ equal to 5\%). In the honey harvested at day 146 (113 days after adding supers), TC concentrations had dramatically decreased. All samples from the treated groups ( $\mathrm{S}$ and $\mathrm{P}$ ) contained TC residues with values ranging from 0.87 to $1.94 \mathrm{mg} \cdot \mathrm{kg}^{-1}\left(\right.$ mean $\left.=1.54 \mathrm{mg} \cdot \mathrm{kg}^{-1}\right)$ and 0.07 to $0.80 \mathrm{mg} \cdot \mathrm{kg}^{-1}\left(\right.$ mean $\left.=0.35 \mathrm{mg} \cdot \mathrm{kg}^{-1}\right)$ in groups $\mathrm{S}$ and $\mathrm{P}$ respectively.

In group $\mathrm{C}$, the mean residue level in honey increased as a result of the contamination by drifting of 4 of the 6 hives of the group with concentration ranging from 0.05 and $0.66 \mathrm{mg} \cdot \mathrm{kg}^{-1}$ (mean for the 6 hives $\left.=0.15 \mathrm{mg} \cdot \mathrm{kg}^{-1}\right)$. It is worthwhile to note that in 2 hives of group $\mathrm{C}$, the contamination was as high as the level measured in several hives of group $\mathrm{P}$ whereas it did not reached values observed in group S.

In all hives of the group DC, no residues were detected at any time of the study. As expected, no drifting occurred from the treated colonies which were $3 \mathrm{~km}$ apart. Each super individually 
identified were removed at day 146 (5 August 2003) then replaced on their respective hive at day 390 (5 April 2004). The honey gathered at day 504 (28 July 2004) did not contained any detectable TC residue, except in one super from group $\mathrm{C}$ with a value of $0.026 \mathrm{mg} \cdot \mathrm{kg}^{-1}$.

Data on the correlation between the amount of antibiotics in honey and the doses given as treatment are scarce. Such a correlation has been extrapolated by Douault et al. (1974) following the feeding of colonies with 4 litres of saccharose syrup marked with ${ }^{141} \mathrm{Ce}: 46$ days following the last administration of 1 litre of syrup and 40 days after adding supers, they demonstrated by autoradiography of a frame the flow of marked syrup to supers. The radioactivity in supers ranged between 2.4 and $6.3 \%$ of the theoretical residual radioactivity. According to these authors, this indicated that bees had moved 2.0 to $8.4 \mathrm{~g}$ of saccharose into every $\mathrm{kg}$ of honey gathered in supers. Hypothesising that antibiotics distributed in syrup would follow the same flow as sugar, they concluded that a mean of $0.21 \%$ of an hypothetical antibiotic dose should finally be found in honey. This evaluation is seven times lower than our experimental mean value of $1.5 \%$ of TC dose found in group S.

Comparison between tetracycline concentration in brood chambers and in supers

In every group, the TC concentration in honey from supers was significantly correlated to the TC concentration in honey from brood chambers measured the same date (table 2).

[Insert table 2 about here]

The correlation coefficient always lower than 1 and the constant term always not significantly different of 0 indicate that the TC concentration in honey from supers was in average always lower than the TC concentration in honey from brood chambers. The correlation coefficient decrease between day 48 and day 146 shows that the TC concentration in honey decreased more rapidly in supers than in brood chambers. This diminution in TC concentration was not due to a simple dilution of TC in the increased quantity of honey as no correlation could be demonstrated between 
the mass of honey harvested in the hive and TC concentration of this honey, or between the mass of honey harvested in the hive and the variation of TC concentration in brood chamber from day 22 to day 146. The amount of TC harvested with honey can be estimated to a range of 1.1 to $11.3 \mathrm{mg}$ and 13.0 to $29.8 \mathrm{mg}$ for groups $\mathrm{P}$ and $\mathrm{S}$ respectively which represented 0.07 to $0.75 \%$ and 0.9 to $2 \%$ of the TC dose applied in powdered sugar or syrup respectively.

These observations are in accordance with the results of Matsuka et al. (1990) who described a transitory increase in OTC concentration in honey from central combs until 5 to 7 days after treatment. They shown that this increase was not a result of water condensation in stored honey as there was no significant increase in sugar concentration but should be due to a new distribution of the medicated store by bees. After a week or more, they observed no apparent difference between the central combs and those next to the feeder comb.

Half-life time of TC in honey in brood chambers and supers

Considering the samples from brood chambers, all linear adjustments according to the degradation speed model (1) were highly significant (Prob (theoretical $\mathrm{F}$ for 1 and 9 degrees of freedom $>\mathrm{F}_{\mathrm{obs}}$ ) $<0.0001)$. Determination coefficient $\left(\mathrm{r}^{2}\right)$ were $0.89,0.78$ and 0.92 for group $\mathrm{C}, \mathrm{S}$ and $\mathrm{P}$ respectively. The degradation rate $\mathrm{k}$ and the $\mathrm{t}_{1 / 2}$ of $\mathrm{TC}$ have been evaluated for the time interval day 1 to day 504, except for group C, for which the time interval was day 22 to day 504, as in this group, TC level increased until day 22 . $\mathrm{k}$ was evaluated to $8.010^{-3}, 12.610^{-3}$ and $12.110^{-3}$ day $^{-1}$ for group C, S and P respectively.

We observe that the evaluations of the half-life time of TC in hives varied from 55 to 87 days, and were lower than the 121 days evaluated for honey stored at $35^{\circ} \mathrm{C}$ under laboratory conditions. Considering honey from supers, due to the limited number of measures and to the limited variation of TC concentration during the period, the calculated half-life time values (77, 60 and 57 days for 


\begin{abstract}
group $\mathrm{C}, \mathrm{S}$ and $\mathrm{P}$ respectively) are non significant. Whereas, these values are very close to the $\mathrm{t}_{1 / 2}$ obtained for honey in brood chambers of the same groups.
\end{abstract}

In summary, TC decline in honey was more rapid in hive than when stored under laboratory conditions at $35^{\circ} \mathrm{C}$. Whereas we did not measured the actual temperature in the hive in this experiment, hive temperature is considered to be equal to $35^{\circ} \mathrm{C}$ and fairly constant due to regulation by bees even if the external temperature is above $38^{\circ} \mathrm{C}$ (which was the case during summer 2003) (Morse 1990). This raises the question of an active decline of TC by bees.

\title{
Conclusion
}

Tetracycline application in hives following protocols usually practiced in France with syrup or powdered sugar demonstrated that the antibiotic is very rapidly incorporated into honey. One day after the last TC application, treatment with syrup resulted in a concentration of TC ten times higher than in honey treated with powdered sugar : mean values were 4.34 and $40.7 \mathrm{mg} . \mathrm{kg}^{-1}$ for groups $\mathrm{P}$ and S respectively. After approximately one year (358 days), mean TC residue levels in brood chambers were 0.13 and $2.57 \mathrm{mg} \cdot \mathrm{kg}^{-1}$ respectively and after 504 days, residue levels became weak. Honey collected on day 146 had mean TC levels equal to 0.35 and $1.54 \mathrm{mg} \cdot \mathrm{kg}^{-1}$ in these groups but no detectable residues in honey harvested on day 504. Storage temperature and probably activity of bees influence the half-life time of TC in honey : (i) the degradation of TC in honey kept in jars is twice faster at $35^{\circ} \mathrm{C}$ compared to $20^{\circ} \mathrm{C}$ and (ii) the estimated $\mathrm{TC}$ half-life time in honey is twice lower in hive $\left(\mathrm{t}_{1 / 2}=65\right.$ days $)$ than when stored under laboratory conditions at $35^{\circ} \mathrm{C}\left(\mathrm{t}_{1 / 2}=121\right.$ days $)$.

Consequently, the relative stability of TC in honey requires appropriate regulatory measures for asserting honey quality. Either, no honey should be allowed for human consumption following a treatment of the colony with antibiotic during the year, or MRL or tolerance values for antibiotics should be defined. Our data could contribute to this definition. 
An important observation is that the honey of non-treated hives may be contaminated with TC through drifting from TC treated neighbouring hives. The contamination occurred from the $1^{\text {st }}$ day until three weeks after treatment and entailed TC concentrations in honey of the same order of magnitude as those measured in some treated hives (mean equal to $0.15 \mathrm{mg} \cdot \mathrm{kg}^{-1}$ in honey harvested on day 146). Moreover, one hive of this control group still contained detectable residues at day 504 $\left(0.026 \mathrm{mg} \cdot \mathrm{kg}^{-1}\right)$. This contamination is related with distance between hives : all contaminated hives were located within 20 to 35 metres from the nearest treated hives, whereas no residues were detected in control hives located $3 \mathrm{~km}$ apart.

\section{Acknowledgements}

We thank Mr B. Delepine and Mr M. Laurentie from AFSSA Fougères for their advice. 


\section{References}

Chambonnaud, J.P., 1968, Contribution à la recherche des antibiotiques dans le miel. Bulletin Apicole de Documentation Scientifique et Technique et d'Information, 9, 133-197.

Courtois, G., Lecomte, J., 1958, Sur un procédé de marquage des abeilles butineuses au moyen d'un radioisotope. Comptes-rendus de l' Académie des Sciences., 247, 147-149.

Douault, P., Louveaux, J., Theurkauff, J., Azoeuf, P., Pintena, J., 1974, Etude du stockage des réserves par les abeilles au moyen d'un sirop de sucre marqué au ${ }^{141} \mathrm{Ce}$. Apidologie, 5, 107-126.

Evans, J.D., 2003, Diverse origins of tetracycline resistance in the honey bee bacterial pathogen Paenibacillus larvae. Journal of Invertebrate Pathology, 83, 46-50.

Faucon, J.P., Martel, A.C., Antinelli, J.F., Clément, M.C., Zeggane, S., Cordella, C., Davico, R., Rognone, C., Aurières, C., 2001, Sondage sur la qualité des miels de lavande-lavandin. Annales de Falsification et d'Expertise Chimiques, 91, n $956,251-261$.

Jürgens, U., 1981, Zur hochdruckflüssigchromatographischen Analyse von Arzneimittelrückständen in Honig. Zeitschrift für Lebensmittel Untersuchung und Forschung, 173, 356-358.

Martel, A.C., Zeggane, S., Aurières, C. and Davico, R., 2003, Bilan du plan de contrôle 2002 de la contamination des miels, Unité de Pathologie de l'Abeille, AFSSA Sophia Antipolis. 9 p.

Matsuka, M., Nakamura, J., 1990, Oxytetracycline residues in honey and royal jelly. Journal of Apicultural Research, 29, 112-117.

McKee, B.A., Goodman, R.D., Saywell, C., Hepworth, G., 2003, Oxytetracycline hydrochloride activity in honey bee larvae (Apis mellifera) following medication with various doses. Apidologie, 34, 269-279. Morse, R.A. (editor) 1990, The ABC\&XYZ of Bee Culture, $40^{\text {th }}$ Edition (Medina : A.I. Root Co.) Nixon, H.L., Ribbands, C.R., 1952, Food transmission within the honey bee community. Proceedings of the Royal Society of London, 140, 43-50.

Note DGAL/SDSPA/SDRRCC/N2002-8031 (18 February 2002), according to European Union Directive 96/23/EC, Ministry of Agriculture, Paris. 
Puyt, J.D., 1997, Antibiotiques - Antibiomimétiques. Cours de chimiothérapie anti-infectieuse et antiparasitaire, Département de Biologie et Pharmacologie, Ecole Nationale Vétérinaire de Nantes, pp. 77-90.

Usleber, E., Dietrich, R., Märtlbauer, E., Unglaub, W., 1996, Antimicrobial residues in honey, Conference of residues of veterinary drugs in food. Euroresidue, Veldhoven, The Netherlands, 948-951. 
Figure 1. Degradation of tetracycline in honey stored in laboratory at 4,20 and $35^{\circ} \mathrm{C}$ 


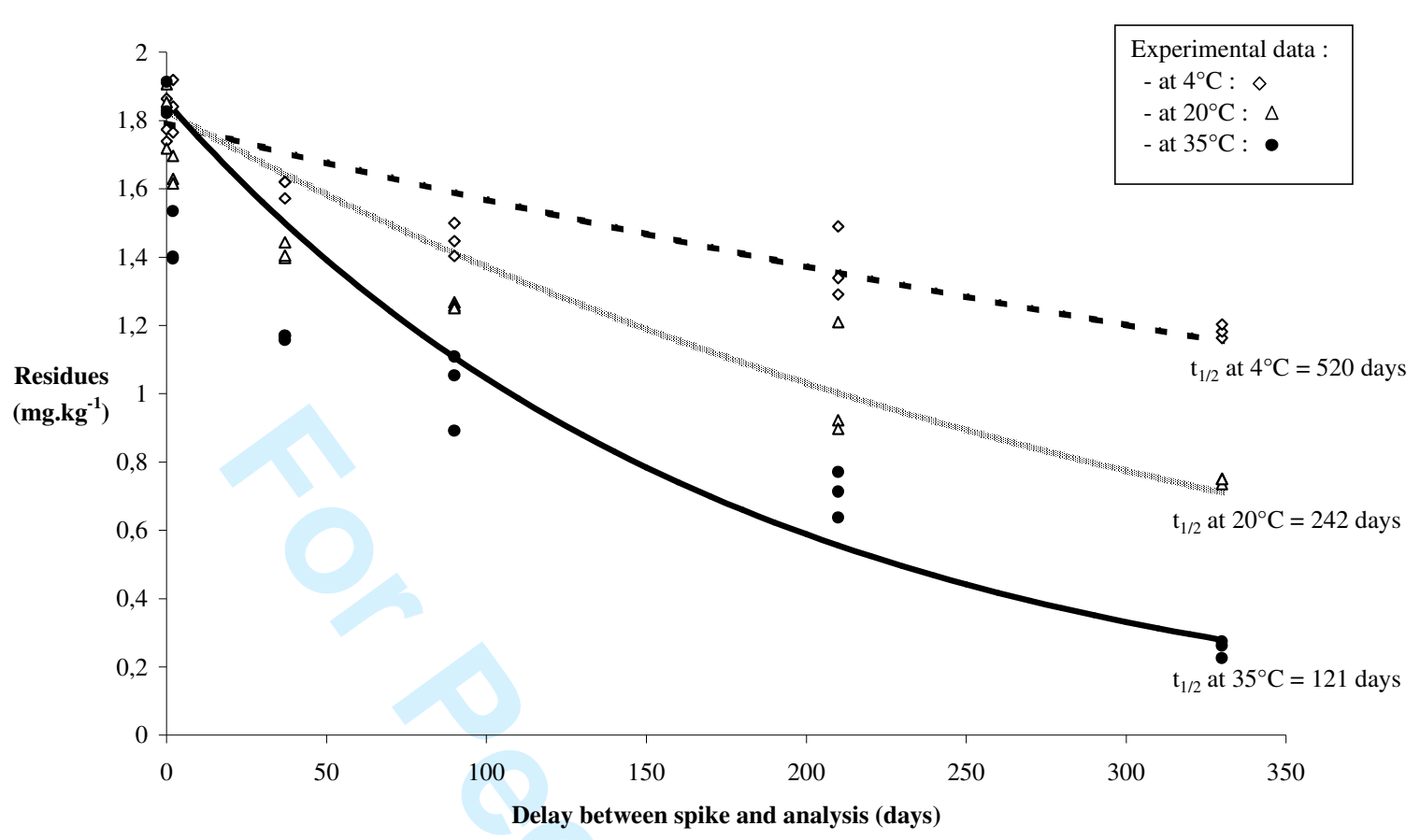


Figure 2. Tetracycline residue levels in honey taken from hives 

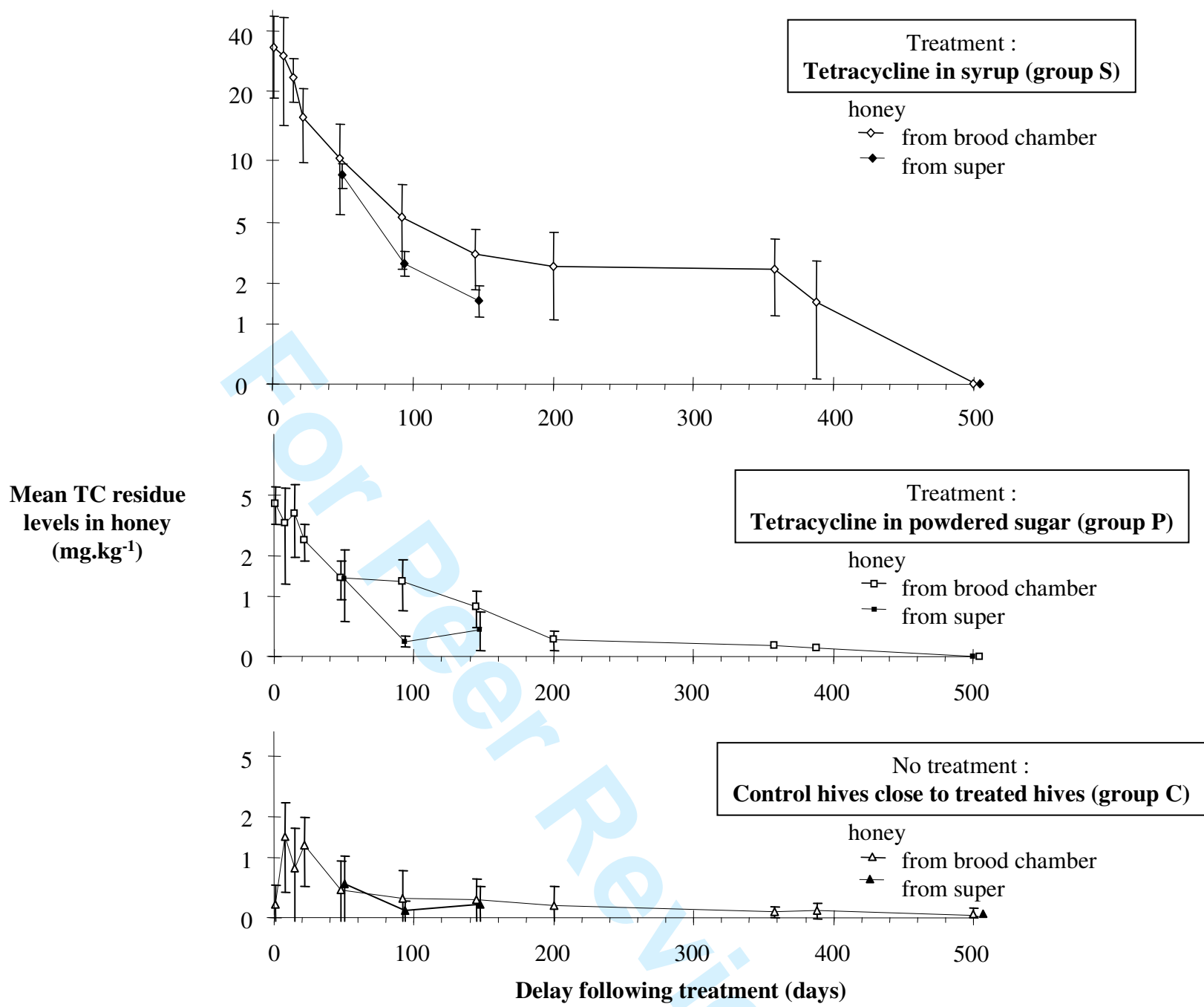
Table 1. Tetracycline residues in hives

\begin{tabular}{|c|c|c|c|c|c|}
\hline $\begin{array}{c}\text { Date of } \\
\text { sampling }\end{array}$ & Sampling & in group DC & $\begin{array}{l}\text { Mean resid } \\
\text { in group } \mathrm{C}\end{array}$ & $\begin{array}{l}\mathrm{s}\left(\mathrm{mg} \cdot \mathrm{kg}^{-1}\right) \\
\text { in group P }\end{array}$ & in group $\mathrm{S}$ \\
\hline $\mathrm{T}-16$ & in brood chambers & ND & ND & ND & ND \\
\hline $\mathrm{D}+1$ & in brood chambers & ND & 0.16 & 4.34 & 40.7 \\
\hline $\mathrm{D}+8$ & in brood chambers & ND & 1.43 & 3.32 & 37.0 \\
\hline $\mathrm{D}+15$ & in brood chambers & ND & 0.72 & 3.82 & 28.8 \\
\hline $\mathrm{D}+22$ & in brood chambers & ND & 1.22 & 2.58 & 18.2 \\
\hline $\mathrm{D}+33$ & & adding supers & $\mathrm{n}$ all groups & & \\
\hline \multirow{2}{*}{$\mathrm{D}+48$} & in brood chambers & ND & 0.37 & 1.36 & 11.2 \\
\hline & in supers & ND & 0.45 & 1.35 & 9.19 \\
\hline \multirow{2}{*}{$\mathrm{D}+92$} & in brood chambers & ND & 0.25 & 1.27 & 5.38 \\
\hline & in supers & ND & 0.08 & 0.18 & 2.82 \\
\hline \multirow{2}{*}{$D+146$} & in brood chambers & ND & 0.23 & 0.72 & 3.22 \\
\hline & in honey harvested in supers & ND & 0.15 & 0.35 & 1.54 \\
\hline $\mathrm{D}+202$ & in brood chambers & ND & 0.14 & 0.20 & 2.72 \\
\hline$D+358$ & in brood chambers & ND & 0.06 & 0.13 & 2.57 \\
\hline \multirow{2}{*}{$D+390$} & in brood chambers & ND & 0.08 & 0.10 & 1.50 \\
\hline & \multicolumn{5}{|c|}{ adding supers in all groups } \\
\hline \multirow{2}{*}{$\mathrm{D}+504$} & in brood chambers & ND & $0.03^{(a)}$ & ND & $0.01^{(\mathrm{c})}$ \\
\hline & in honey harvested in supers & ND & $\mathrm{ND}^{(\mathrm{b})}$ & ND & ND \\
\hline
\end{tabular}

$\mathrm{T}$ : day of the first application of TC

$\mathrm{D}$ : day of the last application of TC

ND : no residue detected
(a) : no residues were detected except in one super with a value of $0.17 \mathrm{mg} \cdot \mathrm{kg}^{-1}$
(b) : no residues were detected except in one super with a value of $0.026 \mathrm{mg} \cdot \mathrm{kg}^{-1}$
(c) : no residues were detected except in one super with a value of $0.043 \mathrm{mg} \cdot \mathrm{kg}^{-1}$ 
Table 2. Comparison between tetracycline concentration in brood chambers and in supers

\begin{tabular}{cccccc}
\hline $\begin{array}{c}\text { Days after } \\
\text { treatment }\end{array}$ & $\begin{array}{c}\text { Determination } \\
\text { coefficient }\left(\mathrm{r}^{2}\right)\end{array}$ & $\begin{array}{c}\text { Correlation } \\
\text { coefficient }(\mathrm{r})\end{array}$ & Significance of $\mathrm{r}$ & $\begin{array}{c}\text { Constant } \\
\text { term }\end{array}$ & $\begin{array}{c}\text { Significance of the } \\
\text { constant term }\end{array}$ \\
\hline 48 & 0.92 & 0.68 & $\mathrm{P}<0.0001-\mathrm{S}$ & 0.36 & $\mathrm{P}=0.32-\mathrm{NS}$ \\
\hline 92 & 0.86 & 0.43 & $\mathrm{P}<0.0001-\mathrm{S}$ & -0.13 & $\mathrm{P}=0.44-\mathrm{NS}$ \\
\hline 146 & 0.74 & 0.40 & $\mathrm{P}<0.0001-\mathrm{S}$ & 0.12 & $\mathrm{P}=0.30-\mathrm{NS}$ \\
\hline 504 & 0.93 & 0.14 & $\mathrm{P}<0.0001-\mathrm{S}$ & -0.001 & $\mathrm{P}=0.35-\mathrm{NS}$ \\
\hline
\end{tabular}

NS : not significant

$\mathrm{S}$ : significant 